\title{
A framework for implementing lean in the Turkish construction industry
}

\author{
Didem Ugurlu1 (iD), Nicky Harris² ${ }^{\text {(D), Sevilay Demirkesen*3 }}{ }^{*}$ \\ ${ }^{1}$ Istanbul Technical University, Department of Architecture, Istanbul, Turkey \\ ${ }^{2}$ University of Salford, Department of Engineering and Environment, Manchester, United Kingdom \\ ${ }^{3}$ Gebze Technical University, Department of Civil Engineering, Kocaeli, Turkey
}

\begin{abstract}
Lean has been widely adopted in the construction industry since the last decade. However, the benefits of practicing Lean have not yet been well understood by construction practitioners. The low productivity and efficiency rates in construction require the implementation of innovative tools and techniques such as Lean construction (LC). However, it is challenging for the construction industry to adopt such new technologies and innovative methodologies. To overcome this challenge, this paper presents a Lean implementation framework for the construction practitioners operating in Turkey. In this respect, questionnaire-based research is conducted with professionals in the Turkish Construction Industry to identify the need, assessment, and implementation scheme for Lean. The framework indicates the importance of planning and management in the implementation process of LC. Moreover, it provides a roadmap for the organizations to implement LC successfully. The framework encourages organizations to analyze and identify their current state and create their value stream mapping along with developing a new policy and strategy for the lean culture. The results of this study are expected to guide construction practitioners with the implementation of LC and practice the components of the framework developed in the context of this study.
\end{abstract}

\section{Keywords}

Construction; Lean; Success; Implementation; Turkey

Received: 22 April 2021; Accepted: 04 September 2021

ISSN: 2630-5771 (online) (C) 2021 Golden Light Publishing All rights reserved.

\section{Introduction}

The construction industry has an important role in economic growth of many countries [1]. The construction industry plays a key role in the national economy of Turkey and contributes to the economic growth [2]. However, since 2015, it is observed that its share in GDP has decreased aligned with the shrank in the growth momentum of the industry [3]. Despite the positive expectations on the industry beginning of 2020, the COVID-19 outbreak negatively impacted the construction business. Several projects were either canceled or delayed causing a huge cost burden on construction firms [4]. Looking at the root cause, many problems are arising from the internal dynamics of the construction industry. Since construction projects are dynamic and complex [5], managing them with conventional approaches leads to delays as well as cost and time overruns [6]. Moreover, the construction industry suffers from a lack of investments in terms of innovating the industry

\footnotetext{
Corresponding author

Email: demirkesen@gtu.edu.tr
} 
such as lack of skilled workers, productivity problems, lack of recovery plans, and poor collaboration [7]. Given this fluctuation in the industry, construction companies need to change in order to remain competitive. Many countries, especially the United Kingdom, are responding to this need by transforming into lean construction that takes its roots from the lean manufacturing approach born in the automotive industry [8].

Lean construction is considered as a new philosophy to manage construction processes [9]. However, LC is not just a change in procedure, it is rather a radical change of the entire business model, construction, and way of thinking [10]. LC aims to eliminate waste and environmental problems along with improving productivity and efficiency [11]. However, it is difficult to stimulate Lean philosophy within the construction industry due to resistance to change. To expand the adoption of LC, it is necessary to provide a complete guide for industry practitioners in terms of encouraging them to utilize lean practices and make them benefit from the practices in the best manner. Considering the barriers behind it, this paper provides a Lean implementation framework for the Turkish Construction Industry. In this respect, the study first presents the research background based on an indepth literature review. Then, the survey conducted with Turkish construction companies is presented to reveal the current situation of LC practices in the industry. Then, the study sets out an implementation framework for LC in the Turkish construction industry.

\section{Lean construction}

Lean was first articulated as a term in the manufacturing industry in the book 'The Machine That Changed The World', published by Womack et al [12]. However, Lean as a philosophy relies on the Toyota Production System developed by Taiichi Ohno, a production engineer from Toyota, after he witnessed the manufacturing industry produces a lot of waste. Lean production (LP) is based on the optimization of production performance to a standard of perfection for fulfilling the unique requirements of customers [13]. It predominantly aims to define value from a customer perspective and reduce the waste from the production processes while improving the quality of product [14].

LP is now practiced and adopted by several industries including construction. It is now being implemented over a wide spectrum of businesses such as logistics and distribution to retail, aerospace, consumer products, metal processing, healthcare, and government institutions' businesses $[8,15]$. Besides, the proven success of LP in the manufacturing industry thrilled the construction industry for implementing Lean principles in construction projects. Hence, the notable improvement provided by the LP triggered the construction industry to implement LC [16].

LC is derived from LP principles [17,18]. Similar to production, LC principles direct the design of construction system to eliminate waste such as time, materials, human effort while generating maximum value with a cost-effective approach [19]. LC rather concentrates on how the value is generated by considering the project as a whole, while traditional construction projects are managed on an activity basis [10].

LC was first coined as a term in August 1993 in the first meeting of the International Group of Lean Construction (IGLC) [20]. Right after, Lean Construction Institute (LCI) was co-founded by Ballard and Howell in 1997 to promote the adoption of Lean principles in the construction industry [21]. Later, with the Egan report published in the UK, LC was promoted for the industry, and since then it has spread all over the world [22]. However, the origin of the Last Planner System (LPS), a Lean construction tool, reaches way back [23]. LPS was discovered by Glenn Ballard and Gregory Howell in the 1990s. The two researchers witnessed inefficiencies in both planning and execution of construction projects resulting in low productivity and high waste. Hence, they proposed the LPS to design out construction processes [24].

While the LPS evolved in the 1990s, Lauri Koskela, a Lean mastermind, also studied the adoption of Lean in the construction industry and became one of the leading researchers who contributed to the expansion of the concept [25]. 
Koskela [26] introduced the TFV (TransformationFlow-Value) theory of production to the construction industry demonstrating an understanding of creating better value for the customer hereby forming the basis of the LC.

LC is a system, which relies on planning and control that enhances project performance. It aims to improve the performance by eliminating waste from the construction processes for increased productivity, enhance health $\&$ safety with satisfied customers [5]. Eliminating wasteful activities, which do not add value to the processes enables the smooth flow of the process [27]. This makes the workflow more predictable leading to shortened project duration and increased project performance [28].

There are several LC tools that organizations gain benefits with implementing, which in turn results in reduced waste and enhanced value [29]. LPS is one of the oldest lean techniques and it allows effective planning and collaboration. It is a tool for production planning and control based on LC principles. It allows planning on a weekly basis according to promises while at the same time providing a master plan, enabling full planning and program development [30]. Moreover, it provides continuous improvement by analyzing the main causes of failure with metrics along with the learning component [20]. LPS improves the predictability and reliability of construction production by providing a collaborative framework that provides coordination, commitment, and transparency between all stakeholders of the project [31, 32].

Besides LPS, there are some other efficient tools and techniques of LC such as 5S, JIT (Just-inTime) delivery, Kanban cards, Kaizen (continuous improvement), concurrent engineering (CE), visual management, Andon, and VSM (Value Stream Mapping). These tools and techniques are either used to eliminate waste or prevent errors in the construction processes. The benefits of using such tools and techniques have already been mentioned in various studies [33-35].

Previous studies also proposed several LC frameworks or models. For example, Paez et al.
[36] proposed a common socio-technological framework, where LP has spread its fundamentals to the construction industry. They implied that both technical and human elements of LP and LC make it possible to form a socio-technological design. In another study, Aslam et al. [37] proposed a framework to select LC tools concerning Lean objectives and functionalities. Their framework heavily relies on the identification of a specific construction process/activity and methodology for the process/activity. The framework also directs making a shortlist of all applicable LC tools, where tools are ranked based on performance. Gao and Low [38] proposed a LC framework based on the Toyota Way model. Their model proposes to focus more on the human side of the LC principles. Their research also criticized existing frameworks and models developed for the fact that process-focus is still the dominant approach among all the LC frameworks developed. Therefore, it is encouraged that more human-focused frameworks are developed to achieve higher success in Lean efforts. Today, LC is considered a construction management approach and is being implemented in many countries. There are significant case studies provided in the LC context from different companies operating in different parts of the world [8]. The major portion of the previous studies mentioned the proven benefits of LC and its implementation in the construction industry [39]. However, the level of implementation and extent of benefits differs in regions. This study investigates the Lean practices in the Turkish construction industry and highlights how Lean is perceived by Turkish contractors.

\section{3. $L C$ in the Turkish construction industry}

Lean has not yet been still adopted well in the Turkish construction industry. Moreover, there is limited research, which investigates LC in the context of the Turkish construction industry. For example, Polat \& Ballard [40] researched the main causes of waste in the Turkish construction industry. They mentioned that failure of the purchased materials to fulfill the requirements of design documents and waiting for these materials to 
change with the proper ones are the main reasons for material and time waste. Besides, Polat et al. [41] investigated the root causes of construction and demolition waste in Turkey. They concluded that the waste in construction and demolition processes is directly related to the design, procurement, and construction. They further implied that Design-bidbuild is the most preferred project delivery system in the Turkish construction industry leading to conflicts in design and change orders. In another study, Can and Taş [42] conducted research to analyze root causes of non-physical waste that affect the construction processes. They found 26 different root causes of waste and determined the probability of encountering them in the industry and their effects on cost, time, and quality waste. Tezel and Nielsen [8] studied the Lean conformance among Turkish contractors. According to their research, there is a lack of awareness of Lean construction among Turkish contractors. However, they concluded that the strong base of the industry is promising for adopting LC principles.

Previous studies highlighted that lack of awareness, lack of training, lack of knowledge among workers, and lack of information sharing are the main barriers hindering the adoption of Lean construction and its implementation in the construction industry [43, 20, 25]. Similar barriers apply to the Turkish construction industry. However, the reasons behind such barriers may vary. For example, the Turkish construction industry rather relies on conventional methods and it has a conservative nature in practice, which eventually leads to resistance to change. The construction industry is considered the leading sector in Turkey and profit margins are quite high. This results in unwillingness for adopting the change. However, there has been a considerable shrinkage recently, which is an alarming situation for the future of the industry. Hence, the industry must change the direction towards adopting the change and developing ways for innovating. Thus, this study presents a framework, which will lead industry practitioners to adopt Lean principles and implement Lean construction in their projects for promoting the change and experiencing higher success rates.

\section{Research methodology}

This study aims to investigate the level of the current understanding of the Lean Approach and its implementation in the Turkish Construction Industry. Researching level of the current understanding of the industry needs to be done in a more positivist and realistic way. However, this research needs a wide variety of interpretations to determine the general perceptions of construction professionals in natural settings. The qualitative approach answers "why" and "how" questions in order to understand the situation while the quantitative approach provides the researcher with a generalized conclusion from a sample to the population of interest. This research utilizes a mixed method of the research approach. The adoption of the mixed method has a significant role which leads the research to carry out the strategy to develop the enquiry [44]. Moreover, the utilization of both quantitative and qualitative approaches provides high reliability of collected data and information that is researched in detail. Therefore, the mixed-method approach is used in the study.

For the quantitative approach, a questionnaire was designed administered to construction professionals operating in Turkey to observe the awareness for Lean construction in the Turkish construction industry. The questionnaire attempted to measure the general awareness of LC in the Turkish construction industry. The questionnaire was distributed to various professionals from the Turkish construction industry. The respondents voluntarily participated in the research through an advertisement on the social network. A total of 52 participants from all over Turkey responded to the questionnaire. The majority of the respondents were architects and civil engineers, who were committed to advancing Lean in their organizations. The respondents mostly worked for clients and contractors based on the type of organization.

The questionnaire consists of two sections, which might be found in the Appendix. The first part of the questionnaire intended to collect data 
about the respondent profile. Queries in this part are related to the background of responders. The main business area, the profession of responders, size of the organizations in which responders work are asked. The responding organizations were arrayed as small, medium, and large size. The second part of the questionnaire aimed at measuring the current awareness and conformance of LC in the Turkish construction industry. The first part aimed to collect general information about responding companies. The second part consisted of questions regarding the current situation of the Turkish construction industry in terms of Lean construction. In this section, the respondents were asked to pick main waste types, report their opinion regarding standardization, waste elimination, culture and change, and customer focus. Moreover, the respondents were further are asked at what level their company has implemented LC and what the success factors and barriers might be affecting its implementation. These questions are close-ended questions with multiple-choice nature. Moreover, to explore the conformance level of the industry, the Lean conformance model proposed by Diekmann et al. [45] is utilized. In the model, there are five categories such as; standardization, waste elimination, culture/people, customer focus, and continuous improvement. Seventeen different questions were developed under these five categories and participants were asked to evaluate them on a Likert scale, where $1=$ Totally Disagree, 2=Disagree, 3= Indecisive 4=Agree, 5=Totally Agree.

i. Questions related to culture and people category investigates organizational structure and culture and companies motivation to change. An example question to this category was "Employees from each level within the company can share their ideas and make prompt decisions to increase efficiency."

ii. Questions related to customer focus ask if the value is defined at the beginning of the project by customer and if the company is flexible to fulfill the customer needs and requirements. iii. Questions related to continuous improvement investigates if risk management techniques are used in the site.

iv. Questions related to standardization ask about if the schedules are visible at the site and working areas tidy and clean.

v. Questions related to waste elimination investigates how planning is processed, how is a stocking, is there any waste between the location of working and stocking areas.

For the qualitative approach, two case study selected to be discussed in the interviews. The first case study is the construction project management department of one of the biggest oil, gas, and energy companies that has operations in around 80 countries. The second case study is a construction company based in Izmir, Turkey, and offers contracting and construction management services. In the interviews, they are asked their understanding of LC, barriers and success factors. The interviews were semi-structured, where each interview was conducted as 30 minutes long. The questions directed in the interviews are provided in the questionnaire as an appendix and open-ended questions were also directed to collect opinion regarding the Lean construction applications in the Turkish construction industry. The participants were selected among the senior-level executives of construction companies. A total of 12 people were interviewed from the selected construction companies.

\section{Findings and discussion}

The first part of the questionnaire collected data regarding the characteristics of the respondents based on their professional background and main business activity. Fig. 1 presents the distribution of respondents by profession. According to this, 52\% of the respondents were architects, $2 \%$ were interior architects, $34 \%$ were civil engineers, $4 \%$ were mechanical engineers, $2 \%$ were geological engineers and $6 \%$ were project managers.

Fig. 2 shows the main business activity of organizations. According to this figure, $17 \%$ of the respondents work for a client company. $2 \%$ is a client representative. $33 \%$ of the respondents are on 
the contractor side. $38 \%$ of participants work for architecture and/or technical design company and $2 \%$ of them were the supplier. There are also participants as consultants or who work for a building audit company, which has $8 \%$ in total.

Table 1 displays the organization size distribution of the surveyed organizations. $34.62 \%$ percent of respondents noted that the organizations they work for are small-scale companies. $30.77 \%$ of the respondents mention that their company is medium-sized. Moreover, $34.62 \%$ of the respondents work in large-sized companies.

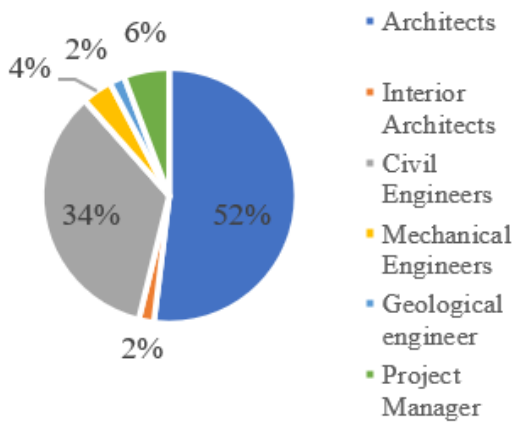

Fig. 1. Respondents by profession

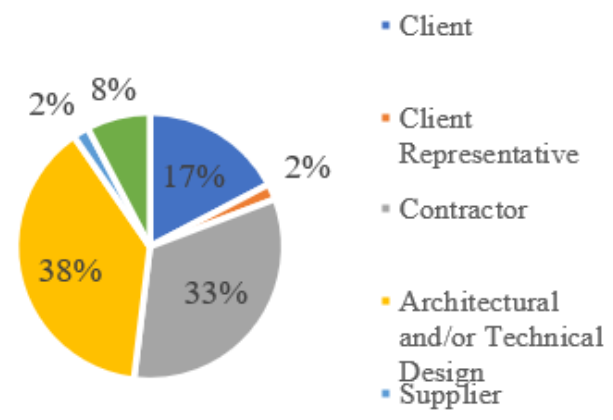

Fig. 2. Organizations' main business activity

Table 1. Organization size

\begin{tabular}{lcc}
\hline Organization Size & Percentage & Number \\
\hline $\begin{array}{l}\text { Small (less than 20 } \\
\text { employees) }\end{array}$ & $34.62 \%$ & 18 \\
$\begin{array}{l}\text { Medium (between 20 } \\
\text { and 50 employees) }\end{array}$ & $30.77 \%$ & 16 \\
$\begin{array}{l}\text { Large (more than 50 } \\
\text { employees) }\end{array}$ & $34.62 \%$ & 18 \\
\hline
\end{tabular}

The second part of the questionnaire provides the current state of LC in the Turkish construction industry based on responses collected. The participants were asked to define the level of understanding and/or use of LC practices in their organizations. Since the questionnaire consists of closed-ended questions, the answers were classified by numbers from the highest frequency to the lowest. Table 2 provides the level of Lean Understanding and Utilization Frequency of Lean tools and techniques.

According to Table 2, the analysis of the questionnaire data indicated that the majority of the participants $(70 \%)$ either stated that they do not have up-to-date information about LC or their organizations do not implement it. $28 \%$ of the participants reported that they have a general idea about LC and its applications but they indicated that they have had no chance to implement it yet in their organizations. The remaining $2 \%$ indicated that their organizations do implement LC in a systemic way.

Lean thinking first appeared in the manufacturing industry. It is now being implemented in the Turkish manufacturing industry with success.

Table 2. Level of lean understanding/utilization frequency

\begin{tabular}{|c|c|c|}
\hline & Number & Frequency \\
\hline $\begin{array}{l}\text { No knowledge about LC } \\
\text { and there is no evidence } \\
\text { that proves the usage of } \\
\text { LC principles, tools and } \\
\text { techniques }\end{array}$ & 35 & $70.00 \%$ \\
\hline $\begin{array}{l}\text { Although there is } \\
\text { awareness about LC, it is } \\
\text { not implemented in the } \\
\text { organisation. }\end{array}$ & 14 & $28.00 \%$ \\
\hline $\begin{array}{l}\text { Implementation of LC is } \\
\text { systemically evidenced in } \\
\text { action. }\end{array}$ & 1 & $2.00 \%$ \\
\hline $\begin{array}{l}\text { LC is interrelated as a } \\
\text { whole and happens } \\
\text { automatically. }\end{array}$ & 0 & $0.00 \%$ \\
\hline $\begin{array}{l}\text { LC is the status quo, } \\
\text { which is challenged to } \\
\text { improve further. }\end{array}$ & 0 & $0.00 \%$ \\
\hline
\end{tabular}


However, the analysis of questionnaire data showed that Lean construction awareness is pretty low in the Turkish construction industry. According to the questionnaire data, $70 \%$ of the participants stated that they do not have awareness for LC. On the other hand, Tezel \& Nielsen [8] mentioned that even though LC is foreign to the companies in Turkey, there is a high level of conformance to the LC practices. Hence, this study collected data regarding the Lean conformance of Turkish contractors. To analyse further the data that is gathered by questionnaire, lean conformance percentage is calculated. Each sub-question has the same weight in terms of lean conformance. However, each given answer is multiplied by the value/weight of the choices. The value/weight of "Strongly Disagree" is 1, "Disagree" is 2, "Indecisive is 3, Agree is 4, "Strongly Agree"' is 5. The answer value refers to the weight rated by each respondent for each question. Answer represents the value of the all ratings within the related question category. The total value is calculated again as below:

Lean Conformance $(\%)=\frac{\left.\sum \text { (Answer Value }\right) \times 100}{\sum(\text { Answer })}$

For every sub-question, the Lean conformance percentage is calculated separately by Eq. (1). Findings were gathered by using the formula above. Eq. (1) forms the Lean conformance values as percentages for each category. The lean conformance values calculated as percentages for each category developed are presented in Table 3.

On the basis of the evaluation of the participants' responses, statistics show that that the Lean conformance value of Turkish Contractors is $64.95 \%$.

Table 3. Lean conformance

\begin{tabular}{lc}
\hline Category & Lean Conformance \\
\hline Standardization & $68.70 \%$ \\
Culture \& People & $60.87 \%$ \\
Continuous Improvement & $58.4 \%$ \\
Customer Focus & $71.33 \%$ \\
Eliminate Waste & $65.42 \%$ \\
Average Lean Conformance & $\mathbf{6 4 . 9 4}$ \\
\hline
\end{tabular}

This value shows there is a quite acceptable foundation to research Lean construction and implement its tools and techniques in the industry. Although most of the professionals from the industry do not have any awareness of Lean construction, the industry has a foundation to go for further implementations. However, the conformance for each category classified under Lean construction should be examined to determine the missing concepts and to corroborate them for better implementation.

The respondents were further requested to indicate the success factors that affect the implementation of Lean construction. Table 4 presents the number and frequency of respondents in evaluating the success factors.

The results presented in Table 4 show that efficient management and planning are revealed as the most significant success factor to implement LC, with a frequency of $72.0 \%$ in all responses. Secondly, $70 \%$ of the participants state that education is very important as a success factor to achieve a successful implementation process. It is followed by the integration of customer centered understanding of the process with a percentage of 62.

Table 4. Success factors of lean implementation

\begin{tabular}{lcc}
\hline Success Factor & Number & Frequency \\
\hline $\begin{array}{l}\text { Efficient management and } \\
\text { planning }\end{array}$ & 11 & $72.0 \%$ \\
$\begin{array}{l}\text { Education \& Training } \\
\text { Customer centered }\end{array}$ & 10 & $70.0 \%$ \\
understanding & 9 & $62.0 \%$ \\
$\begin{array}{l}\text { Efficient change } \\
\text { management }\end{array}$ & 8 & $52.0 \%$ \\
$\begin{array}{l}\text { Integration of stakeholders } \\
\text { Good communication and } \\
\text { coordination between } \\
\text { stakeholders }\end{array}$ & 8 & $52.0 \%$ \\
$\begin{array}{l}\text { Adoption of a continuous } \\
\text { improvement culture }\end{array}$ & 7 & $50.0 \%$ \\
$\begin{array}{l}\text { Efficient working } \\
\text { environment }\end{array}$ & 7 & $48.0 \%$ \\
$\begin{array}{l}\text { Setting a target of } \\
\text { performance and process }\end{array}$ & 7 & $44.0 \%$ \\
$\begin{array}{l}\text { Analyzing Lean } \\
\text { construction }\end{array}$ & 6 & $40.0 \%$ \\
\hline
\end{tabular}


According to the interviewees, one of the most significant factors to implement Lean construction successfully are efficient management and planning, education \& training, adoption of continuous improvement culture and analyzing LC. Since success factors were discussed in detail with the interviewees, it was suggested that success factors are further categorized into groups such as leadership and management factors, organizational and cultural factors, and skills and experience factors. Table 5 presents this classification.

Based on the results of the questionnaire and interviews with the experts, it is apparent that the development of an implementation guide or a roadmap is a must so that awareness is created for a broader community. To fill this gap, this study develops a Lean construction implementation framework to guide industry practitioners with the best Lean tools and techniques and make them benefit from them at maximum.

\subsection{The LC implementation framework for the Turkish construction industry}

LC frameworks, also known as LC models, are guidelines for implementing LC strategies and control and monitor the performance of construction projects [46].

Table 5. Classification of success factors

\begin{tabular}{|c|c|c|}
\hline \multicolumn{3}{|c|}{ Success Factors } \\
\hline $\begin{array}{l}\text { Leadership \& } \\
\text { Management }\end{array}$ & $\begin{array}{l}\text { Organizational } \\
\& \text { Cultural }\end{array}$ & $\begin{array}{l}\text { Skill \& } \\
\text { Expertise }\end{array}$ \\
\hline $\begin{array}{l}\text {-Efficient } \\
\text { management and } \\
\text { planning }\end{array}$ & $\begin{array}{l}\text {-Adoption of } \\
\text { continuous } \\
\text { improvement. }\end{array}$ & $\begin{array}{l}\text {-Education } \\
\text { and } \\
\text { Training }\end{array}$ \\
\hline $\begin{array}{l}\text {-Efficient working } \\
\text { environment }\end{array}$ & $\begin{array}{l}\text {-Integration of } \\
\text { stakeholders }\end{array}$ & $\begin{array}{l}\text {-Analyzing } \\
\text { lean }\end{array}$ \\
\hline $\begin{array}{l}\text {-Efficient change } \\
\text { management }\end{array}$ & & construction \\
\hline $\begin{array}{l}\text {-Customer centered } \\
\text { understanding }\end{array}$ & & \\
\hline $\begin{array}{l}\text {-Setting target of } \\
\text { performance and } \\
\text { process }\end{array}$ & & \\
\hline $\begin{array}{l}\text {-Good } \\
\text { communication and } \\
\text { coordination } \\
\text { between parties }\end{array}$ & & \\
\hline
\end{tabular}

Hence, a generic framework is needed to promote the implementation of LC and eventually improve performance levels in construction projects. In this respect, this study proposes a framework to provide a road map for the Turkish contractors aiming to utilize LC tools and techniques.

The proposed framework is based on the Lean Enterprise Institute (LEI)'s [47] action plan (https://www.lean.org/whatslean/gettingstarted.cf m) that aims to guide the construction industry for LC implementation efforts. The framework comprises four stages (See Fig. 3) that rely upon the action plan items such as finding a change agent, developing a strategy for growth and steering to targets, encouraging Lean thinking, and implementing Lean. The framework was developed based on the responses provided by the respondents of the questionnaire, who clearly emphasized that management and planning, change management, and customer focus are core success components for succesful Lean implementation. The framework further reflects the discussions conducted with the interviewees, who explicitly pointed out that leadership and teamwork are of utmost importance to successfully implement Lean and completing transformation within the organization. Stage 1 identifies the need for change. It sets out the actions necessary for the implementation of the set goals. Stage 2 directs the development of strategies and policies needed to implement LC. Stage 3 presents the phase, where the process begins for the strategies and plans determined. The last stage presents the selection of tools and techniques necessary to implement Lean.

According to the presented framework, Stage 1 starts with the identification of the need for change. In LC transformation, the organization must identify its need for change and the driving factors that push it to change [48]. Then it must continue with the recruitment of a change agent to lead the LC transformation successfully. Transformation to Lean organizations is a radical process since there is a significant need for organizational change. Therefore, the change agent system is mostly used for Lean transformation to assist the change processes [51]. 


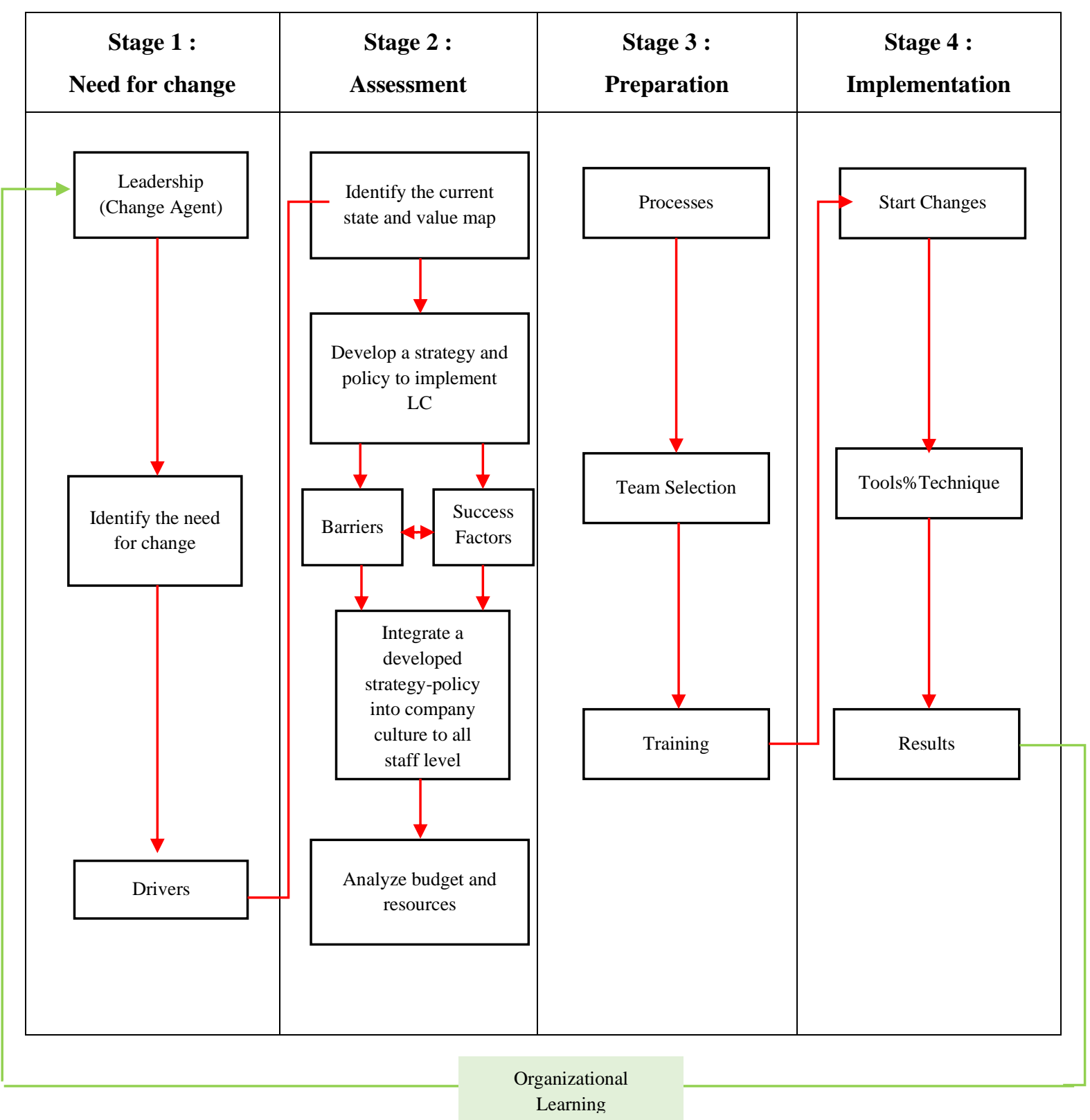

Fig. 3. Proposed lean construction framework

The Lean leader or the change leader should create the environment necessary to adapt the organization to the Lean approach and be part of the strategy [50]. Moreover, the change agent must lead employees resisting change and provide the vision necessary to make the change happen [51].

Stage 2 starts with defining the current state of the organization and mapping the value stream. Consequently, policy and strategy formulation to implement LC is developed. This formulation includes processes and decisions to shape the path, which is to take by the organizations to achieve their goal [52]. The pace and scope of improvement, the expected goals, and the plan to balance and relate the activities should be defined in the context of these strategies and policies [48]. Then, barriers and success factors in the implementation of LC should be identified. The 
culture adopted by the organization and employee behavior can affect the Lean implementation efforts as barriers. These barriers can also affect the performance of the project when it is not managed well [25]. Previous research conducted in Lean for other countries indicated that the main barriers in front of Lean implementation are lack of Lean construction awareness, contracting \& subcontracting problems, financial issues, lack of top management commitment, lack of technology, and lack of client commitment [19, 25]. Moreover, the results of the questionnaire conducted in this study prove that the lack of knowledge and awareness was determined as a major setback for the successful Lean in the Turkish construction industry. Hence, the framework developed in this study is expected to guide Turkish construction practitioners in terms of developing and devising strategies, and revisiting those accordingly to experience higher success in Lean implementation. On the other hand, a considerable portion of the studies investigated the success factors in the Lean implementation. When success factors are determined properly, they smoothen and make the Lean implementation process easier [48]. According to Demirkesen \& Bayhan [35], management commitment, Lean training, and customer satisfaction were listed as the main success factors for a successful Lean implementation process. Moreover, this research revealed that efficient management and planning is a major success factor as reported by the respondents.

Stage 3 is the preparational part of the framework. It begins with improving the processes. As part of this process, the Lean team should be selected based on their skills, capabilities, and openness to change. Moreover, an effective working team to implement LC should be well chosen. An effective team should be collaborative, cross-trained, multi-skilled, and open to change as well as helping others in case of conflict [53]. Moreover, training should be provided to the team to promote the change, involvement in the process, and eliminate the barriers to the Lean implementation process [16]. Besides training the team, periodic coordination meetings (i.e. huddle meetings) should be conducted between stakeholder teams. Plenary sessions should also be coordinated to exchange experiences, failures, and successes [44].

Stage 4 is the last step of the whole process. Successful Lean implementation requires a successful combination of Lean tools and techniques to complete the system so that it cannot operate independently [54]. When appropriate tools and techniques are integrated into the process, the organization becomes able to create a stable process.

Implementation of LC in Turkey is a behavioral and organizational change in the industry. Therefore, an effective change management system should be implemented. One of the change management models that is developed by Kurt Lewin in 1950 plays a very important role during the implementation process. A successful implementation process involves three steps. Lewin believes that unfreezing stage has a significant role in change management. It is the preparation stage, where the industry makes the environment ready for change. In this manner, professionals from all levels in the industry will be more receptive to the new thoughts [55]. To prepare for the change in the Turkish Construction Industry, it is vital to challenge the beliefs, states of mind, and practices that currently characterize the organization [56]. Lewin's force field analysis technique is used to identify the driving and resisting factors for Lean implementation in Turkey. The force field analysis lists the factors, which force organizations to change and which form a barrier to that [57]. The force field analysis is presented in Fig. 4. The factors that drive change and those that resist in the force field analysis are determined based on the data provided by the respondents and interviews conducted with the industry experts. This type of analysis help to take early action, where the root cause is detected. According to Figure 4, one might advocate that Lean implementation in the Turkish construction industry is driven by eliminating time and budget concerns, where lack of information and experience resists the elimination. 


\begin{tabular}{|c|c|c|c|c|c|c|c|c|c|c|c|c|}
\hline \multicolumn{13}{|c|}{ Force Field Analysis for Lean Implementation in Turkey } \\
\hline \multirow{2}{*}{$\begin{array}{c}\text { Driving Factors } \\
\text { (Drivers) }\end{array}$} & \multicolumn{11}{|c|}{ Force Field Analysis } & \multirow{2}{*}{$\begin{array}{c}\text { Resisting Factors } \\
\text { (Barriers) }\end{array}$} \\
\hline & +5 & +4 & +3 & +2 & +1 & 0 & -1 & -2 & -3 & -4 & -5 & \\
\hline $\begin{array}{l}\text { Elimination of time and } \\
\text { budget delays }\end{array}$ & & & & & & & & & & & & $\begin{array}{l}\text { Lack of information and } \\
\text { experience }\end{array}$ \\
\hline $\begin{array}{l}\text { Elimination of wastes and } \\
\text { non-value added } \\
\text { operations }\end{array}$ & & & & & & & & & & & & $\begin{array}{l}\text { Lack of training and } \\
\text { education }\end{array}$ \\
\hline $\begin{array}{l}\text { Efficient management and } \\
\text { predictability }\end{array}$ & & & & & & & & & & & & $\begin{array}{l}\text { No moral and financial } \\
\text { support }\end{array}$ \\
\hline Customer satisfication & & & & & & & & & & & & $\begin{array}{l}\text { The resistance of } \\
\text { employees against change }\end{array}$ \\
\hline $\begin{array}{l}\text { More efficient } \\
\text { communication between } \\
\text { teams }\end{array}$ & & & & & & & & & & & & Lack of communication \\
\hline $\begin{array}{l}\text { Development on work } \\
\text { health, safety and security }\end{array}$ & & & & & & & & a & & & & Bureaucratic barrier \\
\hline $\begin{array}{l}\text { Sustainable building } \\
\text { process }\end{array}$ & & & & & & & & & & & & Financial barriers \\
\hline Quality on production & & & & & & & & & & & & $\begin{array}{l}\text { Long implementation } \\
\text { period }\end{array}$ \\
\hline $\begin{array}{l}\text { More efficient risk } \\
\text { management }\end{array}$ & & & & & & & & & & & & $\begin{array}{l}\text { Barriers within company } \\
\text { and organizational culture }\end{array}$ \\
\hline $\begin{array}{l}\text { Decrease on life cycle } \\
\text { cost }\end{array}$ & & & & & & & & & & & & $\begin{array}{l}\text { Long list of supply chain } \\
\text { and lack of trust }\end{array}$ \\
\hline \multicolumn{7}{|c|}{ TOTAL: 54.4} & \multicolumn{6}{|c|}{ TOTAL: 43.5} \\
\hline
\end{tabular}

Fig. 4. Force field analysis for lean implementation in Turkey

\section{Conclusions}

The construction industry has several challenges faced out requiring the need for change. Hence, the industry is in need of proper tools and techniques to promote innovation and change the culture. In this respect, LC is an effective means of changing the organizational culture and lead employees to produce effective work. The current trend of the construction industry in Turkey indicates that the industry needs more efficient processes and working strategies. To make this possible, the organizations seek different approaches and develop ways to improve the organizational performance. This study investigated the current awareness for LC in the Turkish construction industry. In this context, a questionnaire was designed and administered to construction professionals operating in Turkey. The results of the data analyses revealed that there is a considerable lack of awareness in terms of Lean and its applications in Turkish construction industry. This also indicated that the industry practitioners are not quite familiar with the Lean tools and techniques. This led to the development of a framework, which acts as a roadmap of guidelines for the Turkish construction industry illustrating the best Lean implementation scheme. The framework presents the steps required to implement $\mathrm{LC}$ in a construction project. The framework consists of the elements of leadership and management, driving forces, policies and strategies, barriers and success factors, team selection, training, initial changes, and tools and techniques.

However, the study has some limitations such as low sample size for the questionnaire and lack of experience of Turkish contractors with Lean. Moreover, the framework developed represents the opinions of a relatively small group, where the results might change in the case of larger populations. The framework might also fail to be generalizable for other regions in other countries. Therefore, it is suggested that larger sample sizes shall be employed to form a more representative framework along with the data collected in different regions.

Despite the above mentioned limitations, the framework is expected to guide industry 
practitioners in terms of getting familiar with Lean and its implementation along with developing an understanding of efficient Lean tools and techniques. As future work, similar frameworks might be developed for other countries and the results might be compared accordingly.

\section{Ethics Committee Permission}

This study was conducted while the corresponding author was visiting scholar in abroad. The author(s) confirm that no ethics committee permit is necessary for data collection via questionnaire, but special permissions have been obtained from the company owners to fill in the questionnaire of their employees.

\section{Declaration of conflicting interests}

The author(s) declared no potential conflicts of interest with respect to the research, authorship, and/or publication of this article.

\section{References}

[1] Öcal E, Oral EL, Erdis E, Vural G (2007) Industry financial ratios-application of factor analysis in Turkish construction industry. Building and Environment 42(1):385-392.

[2] Gundes S (2011) Exploring the dynamics of the Turkish construction industry using input-output analysis. Construction Management and Economics, 29(1):59-68.

[3] KPMG (2020). Sektörel Bakış. Available at https://assets.kpmg/content/dam/kpmg/tr/pdf/2020 /01/sektorel-bakis-2020-insaat.pdf

[4] Gamil Y, Alhagar A (2020) The impact of pandemic crisis on the survival of construction industry: A case of COVID-19. Mediterranean Journal of Social Sciences, 11(4):2039-211.

[5] Ansah R H, Sorooshian S, Mustafa S B (2016) Lean construction: An effective approach for project management. ARPN Journal of Engineering and Applied Sciences, 11(3):1607-1612.

[6] Sorooshian S (2014) Delay-based reliability analysis on construction projects. Life Science Journal, 11(3):104-113.

[7] Koutsogiannis A. Modernise or Die - The Need for Change in Construction. Retrived from Let's Build: https://www.letsbuild.com/blog/modernise-or-die (Accessed date: 04/04/2021).
[8] Tezel A, Nielsen Y (2013) Lean construction conformance among construction contractors in Turkey. Journal of Management in Engineering, 29(3):236-250.

[9] Dinesh S, Sethuraman R, Sivaprakasam S (2017) The review on lean construction an effective approach in construction industry. International Journal of Engineering Research and Modern Education (Special Issue):119-123.

[10] Howell G, Ballard G. Implementing lean construction: understanding and action. 6th Ann. Conf. Intl. Group for Lean Constr., 13-15 Aug. 1998, Guarda, Brazil.

[11] Aslam MS, Huang B, Cui L (2020) Review of construction and demolition waste management in China and USA. Journal of Environmental Management, 264:110445.

[12] Womack JP, Jones DT, Roos D. The Machine That Changed the World. Rawson Associates, New York, USA, 1990.

[13] Howell GA (1999, July). What is lean construction1999. 7th Annual Conference International Group for Lean Construction, July 26-28,1999, Berkeley, CA, pp.1-10.

[14] Erol H, Dikmen I, Birgönül MT (2017) Measuring the impact of lean construction practices on project duration and variability: A simulation-based study on residential buildings. Journal of Civil Engineering and Management, 23(2):241-251.

[15] Iuga MV, Kifor, CV (2013) Lean manufacturing: The when, the where, the who. Revista Academiei Fortelor Terestre, 18(4):404-410.

[16] Salem O, Solomon J, Genaidy A, Luegring M (2005) Site implementation and assessment of lean construction techniques. Lean Construction Journal, 2(2):1-21.

[17] Salem O, Zimmer E (2005) Application of lean manufacturing principles to construction. Lean Construction Journal, 2(2):51-54.

[18] Ghosh S, Burghart J (2021) Lean construction: experience of us contractors. International Journal of Construction Education and Research, 17(2):133-153.

[19] Sarhan J, Xia B, Fawzia S, Karim A, Olanipekun A (2018) Barriers to implementing lean construction practices in the Kingdom of Saudi Arabia (KSA) construction industry. Construction Innovation, 18(2):246-272.

[20] Forbes L H, Ahmed S M (2010) Modern construction: lean project delivery and integrated practices. CRC press. 
[21] Common G, Johansen E, Greenwood D. Survey of the take-up of lean concepts among UK. 8th IGLC Conference, 17-19 Jul 2000, Brighton, United Kingdom, pp. 1-10.

[22] Pekuri A, Herrala M, Aapaoja A, Haapasalo H. Applying lean construction - cornerstones for implementation. 20th Annual Conference of the International Group for Lean Construction, 18-20 July 2012, San Diego, CA, USA, pp. 1-10.

[23] Kalsaas B T (2012) The last planner system style of planning: its basis in learning theory. Journal of Engineering, Project \& Production Management, 2(2):88-100.

[24] Ballard HG. The last planner system of production control. Doctoral Dissertation, University of Birmingham, UK, 2000.

[25] Sarhan S, Fox A (2013) Barriers to implementing lean construction in the UK construction industry. The Built \& Human Environment Review, 6:1-17.

[26] Koskela L. Application of the new production philosophy to construction. CIFE Technical Report\#72, Stanford: Stanford university, USA, 1992.

[27] Radhika R, Sukumar S (2017) An overview of the concept of lean construction and the barriers in its implementation. International Journal of Engineering Technologies and Management Research, 4(3):13-26.

[28] Emuze F, Ungerer H. Change in South Africa construction: lessons from lean thinking. 22nd Annual Conference of the International Group for Lean Construction: Understanding and Improving Project Based Production, June 2014, Oslo, Norway, pp. 1121-1131.

[29] Arif MM, Azmi ABN, Aini J. The effectiveness of lean construction tools in the Malaysian construction industry towards contractor's environmental performance. International Conference on Built Environment and Engineering, October 29-30, 2018, Johor, Malaysia, pp. 01022.

[30] Zaeri F, Rotimi FE, Owolabi JD. The effectiveness of the last planner system in New Zealand construction industry: Towards an empirical justification. the CIB World Building Congress, 30 May - 3 June 2016, Tampere, Finland, pp. 528-539.

[31] Mossman A. Last Planner®: 5+ 1 Crucial \& Collaborative Conversations for Predictable Design \& Construction Delivery. The Change Business Ltd., UK, 2013.

[32] Pellicer E, Cerveró F, Lozano A, Ponz-Tienda JL. The last planner system of construction planning and control as a teaching and learning tool. 9th International Technology, Education and Development Conference, 2-4 March 2015, Madrid, Spain, pp. 4877-4884.

[33] Bajjou MS, Chafi A, Ennadi A (2017) The potential effectiveness of lean construction tools in promoting safety on construction sites. International Journal of Engineering Research in Africa, 33:179-193.

[34] Demirkesen S (2020) Measuring the impact of lean implementation on construction safety performance: a structural equation model. Production Planning and Control, 31(5):412-433.

[35] Demirkesen S, Bayhan HG (2020) A lean implementation success model for the construction industry. Engineering Management Journal, 32(3):219-239.

[36] Paez O, Salem S, Solomon J, Genaidy A (2005) Moving from lean manufacturing to lean construction: toward a common sociotechnological framework. Human Factors and Ergonomics in Manufacturing \& Service Industries, 15(2):233245.

[37] Aslam M, Gao Z, Smith G (2020) Framework for selection of lean construction tools based on lean objectives and functionalities. International Journal of Construction Management, doi: 10.1080/15623599.2020.1729933 1-12.

[38] Gao S, Low SP (2014) The Toyota way model: an alternative framework for lean construction. Total Quality Management \& Business Excellence, 25(56): 664-682.

[39] Alarcón LF, Diethelm S, Rojo O, Calderón R (2011) Assessing the impacts of implementing lean construction. Revista Ingeniería de Construcción, 23(1): 26-33.

[40] Polat G, Ballard G. Waste in Turkish construction: need for lean construction techniques. 12th Annual Conference of the International Group for Lean Construction, August 2004, Denmark, pp. 488-501.

[41] Polat G, Damci A, Turkoglu H, Gurgun AP. Identification of root causes of construction and demolition (C\&D) waste: The case of Turkey. Creative Construction Conference, 19-22 June 2017, Primosten, Croatia, pp. 948 - 955

[42] Can G, Taş EF (2021) Analysis of non-physical waste causes that affect the construction process. Journal of the Faculty of Engineering and Architecture of Gazi University, 36(2):655-668.

[43] Alarcón LF, Diethelm S, Rojo O. Collaborative implementation of lean planning systems in 
Chilean construction companies. 10th Annual Conference of the International Group for Lean Construction, 6-8 August 2002, Gramado, Brazil, pp. 1-11.

[44] Bryman A. Social Research Methods. Oxford University Press, UK, 2016.

[45] Diekmann JE, Balonick J, Krewedl M, Troendle L. Measuring lean conformance. 11th Annual Conference of the International Group for Lean Construction, 1 July 2003, Blacksburg, Virginia, USA, pp. 2-8.

[46] Sarhan J G, Xia B, Fawzia S, Karim A, Olanipekun AO, Coffey V (2019) Framework for the implementation of lean construction strategies using the interpretive structural modelling (ISM) technique. Engineering, Construction and Architectural Management, 27(1):1-23.

[47] Lean Enterprise Institute (LEI) (2021). Lean Action Plan. Retrived from https://www.lean.org/whatslean/gettingstarted.cfm (Accessed date: 04/03/2021).

[48] Ogunbiyi OE. Implementation of the Lean Approach in Sustainable Construction: A Conceptual Framework. Doctoral Dissertation, University of Central Lancashire, 2014.

[49] Nordin N, Belal HM (2017). Change agent system in lean manufacturing implementation for business sustainability. International Journal of Supply Chain Management, 6(3): 271-278.
[50] Womack JP, Jones DT. Lean Thinking: Banish Waste and Create Wealth in Your Corporation. New York: First Free Press, 2003.

[51] Donovan RM (2005) Lean Manufacturing as a Competitive Strategy. Retrived from https://www.reliableplant.com/Read/135/leanmanufacturing-strategy (Accessed date: 02/03/2021).

[52] Forster J. The Principles of Strategic Management. South Melbourne: Macmillan Education Australia, 1996.

[53] Hopp WJ, Oyen MP (2004) Agile workforce evaluation: a framework for cross-training and coordination. Iie Transactions 36(10):919-940.

[54] Drew J, McCallum B, Roggenhofer S. Journey to Lean: Making Operational Change Stick. Springer, 2016.

[55] Burnes B (2004) Kurt Lewin and the planned approach to change: a re-appraisal. Journal of Management Studies, 41(6):977-1002.

[56] Stringham S. Strategic Leadership And Strategic Management: Leading and Managing Change on the Edge of Chaos. iUniverse, 2012.

[57] Hall D, Rees G. Managing Change. In: Rees G, French R. (eds.) Leading, Managing and Developing People, CIPD Publications, 2013, pp. 101-126.

\section{Appendix}

\section{Lean construction survey in the Turkish construction industry}

This questionnaire examines the current state and lean awareness of the industry and help to identify how industry could implement lean construction. Please tick appropriate answers based on your experience.

\section{General Information}

1. What is define the company you work for?

○ Client

- Client representative

- Contractor

- Architectural or Technical Design

○ Supplier

$\circ$ Other (Please indicate)

2. What is the size of your company?
- Small size
(0-20 pp.)
- Middle size
(20-50 pp.)
- Large size
(50-more pp.) 
3. What is your position in the company?
○ Architect
- Interior Architect
- Mechanical Engineer
- Civil Engineer
- Electrical Engineer
- Geological Engineer
- Project Manager
- Quantity Surveyor
- Other (Please indicate)

4. What is the operation area of your company?
○ Airports
- Residential and Commercial Buildings
- Pipe Lines Works
- Industrial Facilities
- Marine and Shore Works
- Infrastructural Facilities
- Tunnel Works Dams
- Strengthening and Restoration
- Highway and Transportation Facilities
- Energy Projects

\section{Current Situation of Turkish Construction Industry}

5. Please choose 5 wastes which you face in Turkish Construction Industry mostly.
$\circ$ Overproduction
- Defects
○ Unnecessary inventory
- Unnecessary waiting
- Unnecessary transportation
- Unnecessary motion
- Inappropriate processing
○ Other

Please determine the statements below by considering the situation of current construction industry of Turkey.

\begin{tabular}{|l|l|l|l|l|l|}
\hline \multicolumn{2}{|c|}{$\begin{array}{c}\text { Totally } \\
\text { Disagree }\end{array}$} & Disagree & Indecisive & Agree & $\begin{array}{c}\text { Totally } \\
\text { Agree }\end{array}$ \\
\hline $\begin{array}{l}\text { Employees from each level within the } \\
\text { company can share their ideas and give } \\
\text { decision to increase efficiency. }\end{array}$ & & & & & \\
\hline b. $\begin{array}{l}\text { Upper-level manager tend to change } \\
\text { organizational structure and culture to } \\
\text { increase efficiency. }\end{array}$ & & & & & \\
\hline c. $\begin{array}{l}\text { Employees tend to change organizational } \\
\text { structure and culture to increase efficiency. }\end{array}$ & & & & & \\
\hline d. $\begin{array}{l}\text { The company endeavours to provide } \\
\text { financial and moral support for changes } \\
\text { within structural organisation. }\end{array}$ & & & & & \\
\hline e. $\begin{array}{l}\text { The requirements and value of the } \\
\text { customer is analysed at the beginning of } \\
\text { the project. }\end{array}$ & & & & & \\
\hline
\end{tabular}




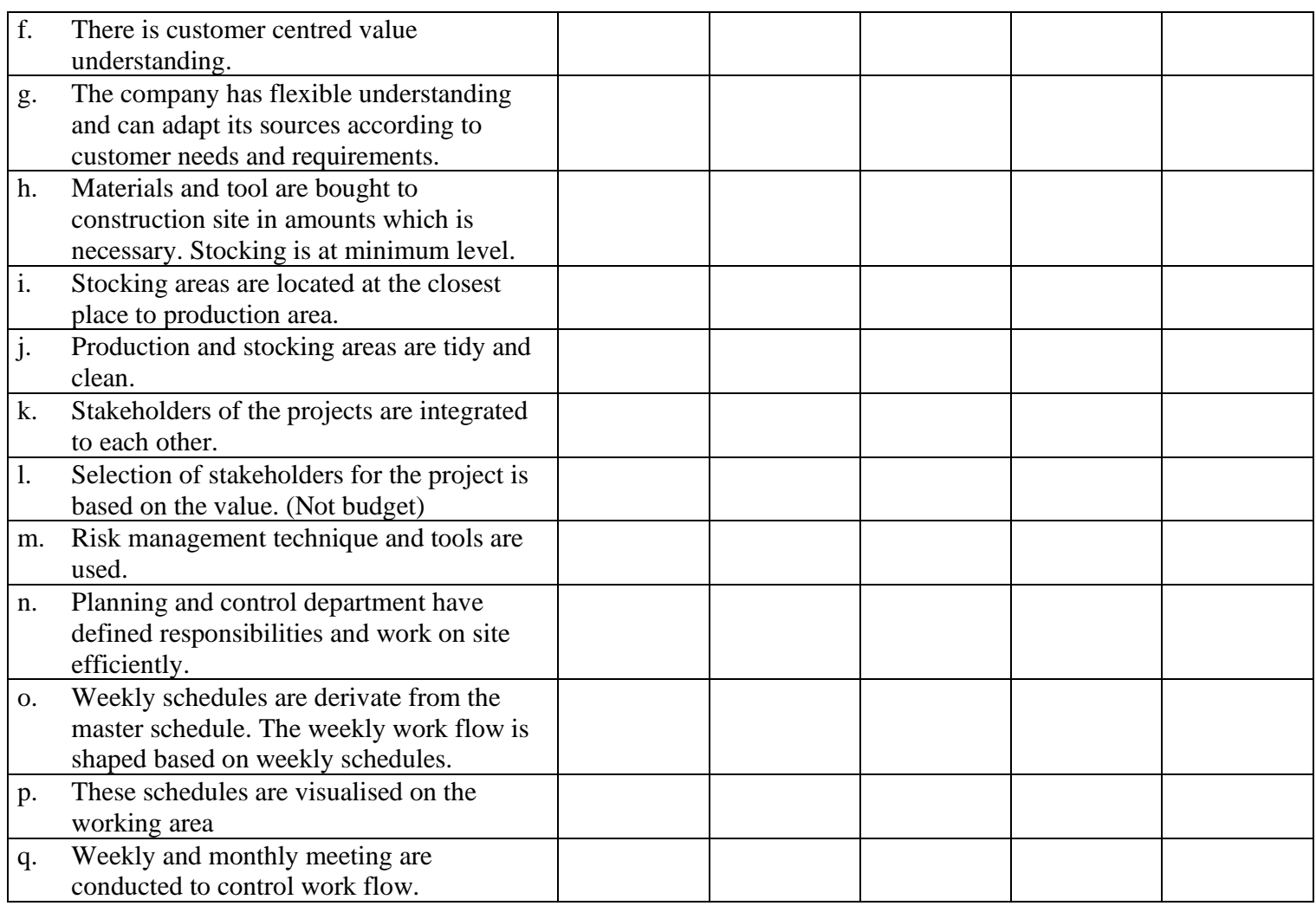

\section{Lean Construction}

6. Which level of Lean Construction is currently implementing in your company.

- The Ideal Statement is hardly evidenced in action.

- Awakening General awareness exists and the Ideal Statement is inconsistently evidenced in action.

- Systematic The Ideal Statement is systemically evidenced in action.

- Integrated The Ideal Statement is interrelated as a whole and happens automatically.

$\circ$ Challenging The Ideal Statement is status quo which is challenged to improve further.

7. What are the barriers/challenges possible to encounter during the implementation of Lean Construction?

- Lack of information and experience

- No moral and financial support provided by the company

- The resistance of employees against to change

- Long implementation period

- Lack of training and education

- Nonconformity of the current construction industry

- Barriers within company and organisational culture

- Bureaucratic barrier

Long list of supply chain and lack of trust

- Lack of communication

- Financial barriers

- Other 
8. What are the core drivers/ estimated benefits of Lean Construction?

- More efficient communication between architectural and technical design teams

- Elimination of wastes and non-value added operations

○ Development on work health, safety and security

$\circ \quad$ Sustainable building process

$\circ$ Elimination of time and budget delays

$\circ$ Quality on production

- Customer satisfaction

- More efficient risk management

$\circ$ Decrease on life cycle cost

$\circ$ Other

9. What are the success factors possible to encounter during the implementation of Lean Construction?

- Efficient management and planning

- Efficient working environment

- Customer centered understanding

- Efficient change management

- Education

- Integration of stakeholders

- Adoption of a continuous improvement culture

- Good communication between stakeholders

- Setting a target of performance and process

- Analysing lean construction

- Other 